\title{
Las cortes de Cádiz y la cuestión indígena, 1808-1814
}

\author{
Samuel Alcides Villegas Páucar \\ Universidad Nacional Federico Villarreal
}

Xavier-Guerra señala que, el primero de los acontecimientos "que marca de una manera definitiva a todo el mundo hispánico", es la abdicación de Bayona ${ }^{1}$, cuando en 1808, Fernando VII, presionado por Napoleón, abdica la corona a favor de su padre Carlos IV, éste a su vez se lo entrega a Napoleón, quien luego termina dejándoselo a su hermano José.

Poco antes, el triunfo inglés de Trafalgar ultima los antecedentes de un poderío militar español relativo, pasando a la lucha por el predominio entre dos grandes potencias, Francia e Inglaterra, que encuentran a Portugal y España en medio del fuego. Una vez que Napoleón decreta el bloqueo continental de Inglaterra, se hace necesario el control de la península. Esto decide la suerte de España, pero, ¿también decide la de las colonias hispanoamericanas?

Observador contemporáneo, Marx señala que el Tratado de Fontainebleau (1807), firmado por Manuel Godoy ante Bonaparte, permitió el reparto de Portugal y la entrada del ejército francés a España, ocasionando la primera oleada revolucionaria (1808-1814) y la guerra de Independencia española, progenitoras de las Cortes gaditanas. Napoleón se hallaba entonces frente a un Estado "muerto", pero la sociedad española rebosaba fuerza de resistencia: a la insurrección en Madrid (que Murat aplasta matando a cerca de mil personas), surge otra en Asturias. Fue un levantamiento espontáneo popular, mientras las clases "bien" se habían sometido mansamente al "yugo extranjero"2.

Secuestrado el Rey español en Francia, se debilitan los lazos que unen a los "reinos" de la monarquía, incluyendo las provincias de ultramar. Las provincias deben reasumir la "soberanía", gobernarlo en nombre del Rey y conservarlo para su soberano legítimo. Para ello, una Junta Central, compuesta por delegados de las juntas provinciales, es creada en septiembre de 1808. En este organismo de gobierno, las provincias ultramarinas estarían representadas por los "diputados".

La Junta Central o Suprema Junta Gubernativa del Reino fue un órgano poco eficaz. No consiguió imponerse a las juntas provinciales, que se proclamaban soberanas, ni organizar la lucha contra la invasión francesa. Cuando Napoleón coloca a su hermano en el trono español, se agrava la crisis del Estado monárquico, arrastrando en dicha crisis a la Junta. En 1809, derrotado el ejército regular y ocupada la mayor parte del país, la Junta, antes de ceder el poder a una Regencia, convoca a las Cortes extraordinarias, para que se

1 GUERRA, Francois-Xavier (1992). Modernidad e Independencias. Ensayos sobre las revoluciones hispánicas. Colección Relaciones entre España y América. Madrid: Editorial MAPFRE, p. 118.

2 MARX, Carlos (1960). Revolución en España. Barcelona: Ariel, p. 96. 
encarguen de crear una legislación y elegir un gobierno. Acorraladas en un punto lejano de la península y separadas durante dos años del núcleo del reino, representaron una España ideal, en tanto que la real seguía combatiendo: en Cádiz, ideas sin acción; en el resto de España, acción sin ideas.

Los primeros movimientos disidentes americanos surgieron en 1810, al saberse la formación de la regencia (considerada ilegítima) y la invasión de Andalucía, haciendo suponer que toda la península había caído ante Francia. De forma casi simultánea, Caracas y Buenos Aires organizaron una junta sobre el modelo de las primeras juntas provinciales españolas. Las Juntas locales asumieron el gobierno provincial, en nombre de Fernando VII.

Luego que la Junta Central preparara el terreno de la convocatoria, la Regencia emitió los decretos para América, el 14 de febrero de 1810. Las Cortes abrieron sus sesiones y fueron declaradas "generales", al representar a todas las provincias de la Monarquía y "extraordinarias", por no haber sido convocadas por el Rey, sino por el "pueblo", para asumir la soberanía y llenar el vacio institucional, y porque era una Asamblea popular, sin representación de la Nobleza y del Clero.

\section{Las elecciones de los representantes americanos}

En medio de la crisis monárquica, se decide convocar a elecciones de representantes en todos los reinos de la Corona ${ }^{3}$. El primer paso a favor de una representación efectiva lo constituyó la creación de la Junta Suprema Central ${ }^{4}$ y Gubernativa del Reino de Indias (1809), partidario de la representación americana, a diferencia del Consejo Supremo de España e Indias, opuesto a los planes "revolucionarios" de la Junta.

El ayuntamiento de la capital de partido elegía al diputado. Se elegía primero a tres individuos naturales de la provincia, dotados de "probidad, talento e instrucción, y exentos de toda nota", y luego se sorteaba el nombre del diputado. "Verificada la elección, recibirá el diputado el testimonio de ella, y los poderes del ayuntamiento que le elija, y se le darán todas las instrucciones que así el mismo Ayuntamiento, como todos los demás comprendidos en aquel partido, quieran darle sobre los objetos de interés general y particular que entiendan debe promoverse en las cortes" . Este decreto ofrece a los americanos un diputado por partido, dando por sentado que todas las capitales de partido tenían ayuntamiento ${ }^{6}$.

La regencia promulgó un suplemento explicativo al decreto, en el que afirma que no debe considerarse la convocatoria como suena, de los españoles nacidos en América y Asia, sino "también de los domiciliados y avecindados en aquellos países, y asimismo de los indios, y de los hijos de españoles e indios". La Regencia prometía incluso "el nombramiento de defensores que representen en ellas (las Cortes) a los indios" mientras arregla "el método con que deberán ellos mismos elegir sus representantes"7.

3 GARCÍA H., Elías, «Las Cortes de Cádiz y las elecciones de los diputados de Cádiz», Revista Chilena de Historia y Geografía, 1912. Otros que han tocado el tema: CHAVARRI S., Pilar; MERINO, Waldo, SUÁREZ V., Federico y RIEU-MILLAN, Marie-Laure, etc.

4 MARTÍNEZ DE VELASCO, Ángel (1972), La formación de la Junta Central. Pamplona: Eunsa.

5 FERNANDEZ, Martín, Colección de los decretos expedidos por las Cortes, 1810, 1824, t. 2, pp. 594-600: Instrucción para las elecciones para América y Asia. 14 de Febrero de 1810. Tambien véase la COLECCION de Decretos y Órdenes de las Cortes de Cádiz, Madrid, Cortes Generales, 1987, volúmenes I y II.

6 DIARIO de sesiones de las Cortes Generales y Extraordinarias (1810-1813), Madrid, Imprenta de J. A. García, 1870. El texto del decreto de Fernando VII (14 de febrero de 1810) dice "capital cabeza de partido", y luego precisa que la elección "se hará por el Ayuntamiento de cada capital". Los miembros de la Regencia no conocían muy bien las divisiones administrativas de América, ni sabían de la escasez de "ayuntamientos" en América. Si hubiesen elegido representante todas las capitales de partido, las provincias ultramarinas habrían tenido muchos más diputados de los esperados. Sólo eligieron los ayuntamientos capitales de provincia.

7 Sobre este punto véase "Las provincias de Ultramar, la representación igualitaria, la discriminación social y racial”, pp. 93-129, en TIERNO G., Enrique (ed.), Actas de las Cortes de Cádiz. Antología. Madrid: Taurus, 1964, Colección Biblioteca Política, (2 tomos), p. 1229. 
Para ser representada se priorizó a la población blanca. Los decretos definitivos incluyeron a los indígenas y mestizos, dejando fuera a las castas pardas ${ }^{8}$, por ser originarias del Africa y porque el decreto no podía modificar el sistema de elección por los ayuntamientos. El nombramiento de defensores indígenas, del que habla el decreto de la Regencia para la elección de suplentes $(08 / 09 / 1810))$, no llegó a realizarse.

Los criollos pidieron una representación idéntica para todos los territorios de la Monarquía española. Se planteó que, para restablecer la confianza de los españoles americanos hacia el gobierno de la metrópoli, era necesario decretar inmediatamente esta igualdad y convocar elecciones complementarias en América. Estas proposiciones, presentadas por una Comisión americana presidida por el quiteño José Mexía Lequerica, fueron objeto de debates muy tensos entre peninsulares y criollos.

Los criollos tuvieron que moderar sus exigencias ante la oposición de la mayoría peninsular. Las cortes aprobaron un decreto que sancionaba el derecho de América a una representación proporcional y anunciaba que la cuestión se trataría "con oportunidad".

El texto decepcionó mucho a los americanos. El 16 de diciembre de 1810 los suplentes criollos presentaron once proposiciones. La primera declara "que la representación nacional de las provincias, ciudades, villas y lugares de la tierra firme de América, sus islas y las Filipinas, por lo respectivo a sus naturales y originarios de ambos hemisferios, así españoles como indios y los hijos de ambas clases, debe ser y será la misma en el orden y forma (aunque respectiva en el número) que tienen hoy y tengan en lo sucesivo las provincias, ciudades, villas y lugares de la península e isla de la España europea entre sus legítimos naturales".

Dado el decreto por el que se eligieron los diputados peninsulares (excluídas las castas pardas de origen africano ${ }^{10}$ ), la discusión empieza el 9 de enero de 1811, a la llegada de los primeros propietarios mexicanos, El 7 de febrero, las Cortes aprobaron por 103 votos contra 4 el principio de igualdad de representación, pero rechazaron 69 votos contra 61 la aplicación del principio a las cortes actuales. La consecuencia fue el artículo 1, del decreto de 9 de febrero de 1811: "Que siendo uno de los principales derechos de todos los pueblos españoles su competente representación en las Cortes nacionales, la de la parte americana de la Monarquía española, en todas las que en adelante se celebren, sea enteramente igual en el modo y forma a la que se establezca en la península, debiéndose fijar en la constitución el arreglo de esta representación nacional sobre las bases de la perfecta igualdad, conforme al decreto de 15 de octubre último"11.

Los diputados serían elegidos según el sistema de las juntas electorales sucesivas. Los electores se reunirían en la Junta electoral de parroquia, para elegir a un número variable de compromisarios, quienes elegirían a los "electores parroquiales". Los electores parroquiales formaban la junta electoral de partido y elegirían a los "electores de partido".

8 KING, James Ferguson, «The Colored Castas and american representation in Cortes of Cádiz», The Hispanic-American Historical Review, volumen 33, N. ${ }^{\circ}$ 1, (Febrero) 1953, pp. 33-64.

9 Decreto de 15 de octubre de 1810, aprobado en sesión secreta el 14 de Enero. En Actas de las sesiones secretas de las Cortes 1810-1814. Publicado por M. Fernández Martín, tomo 2, pp. 630- 631.

10 Para Inés Quintero, el vaticinio de algunos diputados en las cortes de que si no se incluía a los pardos para fijar la representación en las cortes, estos se unirían a los insurgentes atraídos por el discurso de la igualdad, no se cumplió. Abolida los fueros, liquidada la desigualdad, declarada la independencia, roto los vínculos con la monarquía, los pardos, en su mayoría, se mantuvieron afectos a la causa del Rey. QUINTERO, Inés. "Sobre la suerte y pretensiones de los pardos”, p. 327-345. En. FRASQUET, Ivana (Coord.) (2006). Bastillas, cetros y blasones. La independencia en Iberoamérica. Madrid: Instituto de Cultura, Fundación MAPFRE.

11 COLECCIÓN de los Decretos y Órdenes que han expedido las Cortes Generales y Extraordinarias desde su instalación en 24 de septiembre de 1810 hasta igual fecha de 1811, Madrid: Imprenta Nacional, 1820. Ver pp. 57-87. 
La junta electoral de provincia, reunida en la capital provincial, se componía de todos los electores de partido. y presidida por el jefe político, elegía a los diputados y suplentes de la provincia, a razón de un diputado por 70,000 habitantes ${ }^{12}$. Por el sistema electoral de $1810 \mathrm{y}$ la Constitución de 1812, los indígenas iban a ser electores de parroquia, pero resulta evidente que este sistema de filtros sucesivos eliminada prácticamente la representación indígena en las Cortes ${ }^{13}$.

Hubo un total de 303 representantes, 37 provenían de las colonias ( 7 del Virreinato de México, 2 de la Capitanía General de Guatemala, 1 de la Isla de Santo Domingo, 2 por Cuba, 1 por Puerto Rico, 2 de Filipinas, 5 del Virreinato de Lima, 2 de la Capitanía General de Chile, 3 por el Virreinato de Buenos Aires, 3 por Santa Fe, y 2 por la Capitanía General de Caracas). De 37 diputados presidentes, 10 de ellos eran americanos. La misma Comisión encargada de elaborar el proyecto de Constitución se formó con 9 peninsulares y 5 americanos $^{14}$.

En las elecciones constitucionales, cada elector designaba en la mesa electoral de parroquia a 11, 21 ó 31 individuos según el número de compromisarios que cada parroquia debía mandar a la Junta de partido, pero no había lista de candidatos. Esto sugiere que algunos fueron elegidos contra su voluntad, lo que explica las numerosas dimisiones; los renunciantes aducían la edad avanzada o mala salud para no emprender el viaje; los que tenían familia o bienes no estaban siempre dispuestos a alejarse por varios años. Cuando la renuncia era aceptada, había que realizar nuevas elecciones. Hubo casos en los que el nuevo elegido también renunció.

Aunque los electores podían en principio votar libremente, los grupos de poder intentaron imponer a sus candidatos. En las elecciones para las Cortes extraordinarias, el Cabildo elector estaba presidido por el Gobernador. En algunos casos éste designó a los candidatos; el Acta de elección de la ciudad de Puno dice: "dejando a la prudencia, sagacidad, pulso y conocimiento del señor presidente del Cabildo Gobernador, Intendente Don Manuel Quimper el señalamiento de los candidatos"15.

Con una representación americana desigual y heterogénea, los primeros diputados fueron elegidos por los Ayuntamientos de las capitales de las provincias y actuaban a menudo como apoderados de una región determinada, mientras que los elegidos según la constitución, representaban en principio a la nación entera. Las provincias disidentes no mandaron diputados y fueron representadas por algunos suplentes elegidos en Cádiz.

A la representación suplente se le acusaba de un desconocimiento de los problemas del territorio. Por ejemplo, se reprochaba a Francisco Lopez Lisperguer, diputado de Buenos Aires, de que desde su niñez residía en la península. Otro tanto se dijo de Dionisio Inca Yupanqui, suplente por el Perú, hermano de don Manuel Inca Yupanqui, que aparece incluido en las lista de los agentes napoleónicos ${ }^{16}$ en España.

Para Guerra, "Todo el sistema está penetrado por una concepción tradicional y corporativa de la representación. La representación del reino se identifica con la de las ciudades principales, ya que se considera que éstas llevan implícitamente, como su cabeza, la representación de todo su territorio; las ciudades, a su vez, están representadas por sus

12 FERNÁNDEZ G., Antonio, (edición e introducción) (2002). La Constitución de Cádiz (1812), y discurso preliminar a la Constitución. Madrid: Castalia pp. 1-77.

13 RIEU-MILLAN, M. L., Los diputados americanos en las Cortes de Cádiz, ver pp. 3-29 y pp. 40-55.

14 RAMOS, Demetrio, «Las Cortes de Cádiz y América», Revista de Estudios Políticos, n.o 126, 1962, pp. 433-639. También «Las Cortes de Cádiz, como recurso y esperanza», Gades, N. ${ }^{\circ} 16$ (número extraordinario. CLXXV Aniversario de la Constitución de 1812), 1987, pp. 100-120.

15 COLECCIÓN documental de la independencia del Perú (1974). Lima, Tomo IV: El Perú en las Cortes de Cádiz, Vol. 2, pp. 12-24.

16 RAMOS, Demetrio, «Las Cortes de Cádiz y América», Revista de Estudios Políticos, N. ${ }^{\circ} 126,1962$, pp. $433-$ 639. Ver p. 472 y ss. 
Ayuntamientos. Como se trata de elegir procuradores de una serie de cuerpos -ciudades, provincias y reinos- dotados por ellos de instrucciones precisas, están excluidas las candidaturas, y las campañas electorales. El ideal teórico es la unanimidad, pues se trata de escoger "a individuos de notoria probidad, talento e instrucción, exentos de toda nota, que pueda menoscabar la opinión pública", es decir, de seleccionar en función de una dignidad y de cualidades intelectuales y morales, que normalmente deben ser reconocidas por todos"17.

El voto en Venezuela y México fue extremadamente disperso, lo que indica un gran localismo. En México hubo también querellas muy vivas entre facciones -el partido «europeo» contra el "criollo" lo que impidió un voto concertado. En Perú, "los votos aparecen más agrupados, como si los cabildos hubiesen recibido consignas para votar una serie de nombres. El poderío y el influjo de la élite limeña sobre todo el Perú aparecen claramente. El fenómeno es aún más marcado en Chile, reino de población reducida y homogénea, bien controlado por las élites de Santiago"18.

El hecho de que ciudades tan alejadas unas de otras hayan votado sin ninguna campaña electoral por las mismas personas, sólo puede explicarlo la existencia de redes de relación o de influencia de las élites políticas, la acción concertada de las autoridades, o un amplio prestigio de esos hombres. Las tres explicaciones son válidas, y sobre todo las dos primeras.

En suma, para Guerra, el examen de la condición de los elegidos muestra quiénes eran los hombres que los patriciados urbanos consideraban dignos de representar a la sociedad. En los tres reinos, los elegidos son los más altos personajes, por su rango y sus cargos -civiles, militares o eclesiásticos-, de la sociedad del Antiguo Régimen, siguiendo incluso en el orden de los votos las escalas de dignidades ${ }^{19}$. En los bajos peldaños se encontraban párrocos, regidores y más abajo los intendentes interinos, canónigos, miembros de cabildos, oficiales de Finanzas y militares.

Guerra observa partidos en pugna: el examen de la votación misma, el fraude eventual y los reclamos electorales reflejan a los actores de la vida política y sus peleas. En las tres regiones las reclamaciones fueron en general poco numerosas, quizá porque la mayoría de los cabildos estaban bien controlados por un clan de poderosos y sus aliados, pero es excepcional que las elecciones se hagan por unanimidad ${ }^{20}$.

Los problemas que surgían a nivel local impidieron la normal representación de la provincia, como ocurrió en el caso de Cuzco, provincia independiente de Lima, con su Jefe político y su Diputación provincial. La Diputación provincial presidida por el Jefe político se reunió en septiembre de 1813 para iniciar el proceso electoral. Votó un sueldo de 8.000 pesos por diputado y para dos años. Las dos subprovincias (Cuzco y Puno) tenían que elegir cada una a tres diputados y desembolsar 24.000 pesos cada dos años para estar representadas.

El Cabildo del Cuzco eligió a su diputado, José Mariano de Ugarte, pero no tenía dinero para pagarle. Incluso el Virrey se negó a dar su apoyo. La caja de Mojonazgos propuso

17 GUERRA, Francois-Xavier, Modernidad e independencias. Ensayos sobre las revoluciones hispánicas. Colección Relaciones entre España y América. Editorial MAPFRE, 1992, Madrid, P. 57.

18 Ibídem, p.. 196.

19 Ibídem, p. 63.

20 Ibídem, p. 198. Escobar también ha estudiado el proceso electoral ordenado por la Constitución de Cádiz en los pueblos indígenas huastecas de México, como sobrevivió la representación política de los indios y como muchas veces los ayuntamientos constitucionales no lograron asumir el papel que hasta entonces habían desempeñado los gobiernos indígenas. ESCOBAR O., Antonio, "Del gobierno indígena al ayuntamiento constitucional en los huasteques hidalguense y veracruzana, 1780-1853”. Mexican estudies/ estudios mexicanos, 12/1 (invierno, 1996), p. 1-26 
5.000 pesos y la ciudad otros 4.000 pesos. Ugarte contestó que era muy escasa aquella cantidad. Tras dos meses de negociaciones con el Cabildo, Ugarte dimitió. Otro electo, Manuel Plácido de Berriozábal, tampoco quiso irse por falta de dinero. El Cabildo realiza nuevas elecciones y nombra al Oídor Manuel Galeano; en agosto de 1812, Galeano seguía en el Cuzco. A fines de 1812, el Ayuntamiento otorgaba 10.000 pesos. Pero por esas fechas el texto constitucional ya había llegado al Cuzco y había que iniciar el proceso electoral para las Cortes ordinarias. La partida de Galeano era ya inútil.

En Puno hubo al menos cuatro elecciones, pero que nadie pudo irse por falta de dinero. El electo Tadeo Gárate aceptó marcharse con un adelanto de 2.000 pesos y se fue a Lima en octubre, cuando ya se conocía en Puno la Constitución. El Gobernador de Puno y el Virrey Abascal dieron todas las facilidades a este diputado (absolutista y clerical) para que fuera a España.

Las provincias que además contribuían a financiar la guerra contra los insurgentes, no podían estar normalmente representadas ${ }^{21}$. Rieu-Millán pone en evidencia el abismo que separaba las buenas intenciones de las Cortes, y las posibilidades concretas de aplicar sus decretos en regiones tan remotas, y gobernadas por Jefes poco favorables al sistema parlamentario.

También los Jefes políticos actuaron con mala voluntad, retrasando el pago de los sueldos hasta que la partida de los diputados perdiera sentido. Para estas autoridades, la guerra contra los rebeldes era primordial; las elecciones un asunto secundario o peligroso.

Los diputados en las Cortes extraordinarias recibían su sueldo de la ciudad que los había elegido; los diputados constitucionales eran pagados de los propios de las ciudades, aunque después se autorizó a las autoridades locales a utilizar las Cajas provinciales. La ciudad de México pagó lujosamente a su diputado, el canónigo Cisneros. En general, las provincias ultramarinas tuvieron problemas para encontrar el dinero de pago y el derecho a ser representadas costaría muy caro, especialmente a las regiones andinas.

El Perú tuvo que retribuir a cinco suplentes. En marzo de 1812, cuando eligió a «su» diputado, Francisco de Salazar y Carrillo, decide considerar al suplente Vicente Morales Duárez como diputado de la ciudad ${ }^{22}$. Las ciudades peruanas nunca mandaron suficiente dinero para pagar a los suplentes que no consideraba diputados suyos.

De otro lado, en agosto de 1810, se hizo evidente que numerosos diputados propietarios no llegarían a la inauguración de las sesiones. Los residentes en Cádiz, originarios de las provincias no representadas, elegirían entre ellos a un número de suplentes para representar a dichas provincias. Los 177 electores americanos eligieron a 29 suplentes $^{23}$. En total tomaron asiento 86 diputados ultramarinos: 29 suplentes elegidos en Cádiz; 36 propietarios por los Ayuntamientos y 23 diputados constitucionales. Hubo un máximo de

21 Véase RIEU-MILLAN, Marie Laure, Rasgos distintivos de la representación peruana en las Cortes de Cádiz y Madrid: 1810-1814. Madrid, C. S. I. C., 1988. p. 475-515. Otro, El Perú en las Cortes de Cádiz / investigación,_recopilación y prólogo por G. Durand Flores. Lima: Comisión Nacional del Sesquicentenario de la Independencia del Perú, 1974. 2 v.; (Colección documental de la independencia del Perú; 4, 1, 2). También LLONTOP S., Susana, «Antonio de Andueza y Gregorio de Guinea, diputados peruanos electos a las Cortes de Cádiz», en V Congreso Internacional de Historia de América, tomo IV, Lima, 1971, pp. 7-52.

22 PATRÓN, Pedro, «Los peruanos en las Cortes de Cádiz», Revista de la Facultad de Derecho de la Universidad Complutense, N. 93,2000 , pp. 357-362. RAMOS, Demetrio, «Las Cortes de Cádiz y América», Revista de Estudios Políticos, N. ${ }^{\circ}$ 126, 1962, pp. 433-639. También «El peruano Morales, un ejemplo de complejidad americana en las Cortes de Cádiz», Revista de Estudios Políticos, N. ${ }^{\circ} 146,1966$, pp. 139-202. ALAYZA y Paz Soldán, Luis; Pons Muzzo, Gustavo, La Constitución de Cádiz de 1812. El egregio limeño Morales y Duárez”. Documenta: Revista de la Sociedad peruana de historia, $\mathrm{N}^{\circ}$ especial:, Lima, 1948, 1(1) p. 465-466.

23 Repartidos de esta manera: Virreinato de Nueva España (7), Guatemala (2), Santo Domingo (1), Isla de Cuba (2), Puerto Rico (1), Filipinas (2), Virreinato del Perú (5), Chile (2), Virreinato de Buenos Aires (3), Venezuela (2), Virreinato de Santa Fe (3). Eso, de una Hispanoamérica calculada en 16 millones de habitantes, frente a 10 millones de peninsulares. 
50 representantes ultramarinos juntos. Los que asistieron más tiempo fueron los suplentes, especialmente los que representaban provincias disidentes que no mandaron diputados: Venezuela (excepto Maracaibo que tuvo un diputado), Nueva Granada (excepto Panamá), Chile y el Virreinato del Río de la Plata (excepto Montevideo y La Paz).

Las islas antillanas mandaron todos los diputados que les correspondían, México envió 14 diputados a las Cortes extraordinarias, y Perú solamente 8 que, además, llegaron muy tarde. Excepto las Antillas, ninguna provincia llegó a tener todos los diputados que les correspondía.

De los 177 electores americanos, 14 europeos avecindaban en Ultramar. La gran mayoría estaban de paso en Cádiz, eran apoderados de sus provincias ante el gobierno, refugiados de otras regiones españolas ocupadas, etc.. Estas 177 personas no podían sustituir, en derecho, al conjunto de las provincias americanas. La Gaceta de Buenos Aires los calificaba de "representantes de la voluntad ajena", elegidos por "un puñado de aventureros sin carácter ni representación" ${ }^{24}$. Para Fray Servando de Mier, los suplentes caen en un "círculo vicioso" por la ilegitimidad del sistema de suplencia adoptado y porque "no tenían otros poderes que los que se dieron ellos mismos"25.

La crítica incluyó a los miembros de la Junta Central y de la Regencia, autores de este sistema de suplencia. Cuando el magistrado mexicano Miguel de Lardizábal escribe que los suplentes son ilegales porque las provincias no les dieron "ni encargo, ni facultad, ni poder alguno", concluye que las Cortes no tienen poder para modificar las leyes fundamentales del reino mientras no tomen asiento sus diputados elegidos, con las instrucciones o "encargos" de sus comitentes.

Como dijimos, las autoridades (Virreyes, Capitanes Generales y Gobernadores) tenían medios de controlar estas elecciones ya que presidían el Cabildo elector. Las elecciones constitucionales eran convocadas por el Jefe colonial, pero luego se desarrollaban con independencia de él. En México, el Virrey suspendió el proceso electoral, y en Guatemala el Capitán General lo retrasó de modo que ningún diputado llegó a tiempo. Los plazos de ejecución de los decretos eran muy cortos. Bastaba con que el Jefe político tardara en transmitirlos o actuara con mala voluntad, para que los retrasos privaran a las provincias de tener diputados en Cortes.

Respecto a la ocupación, de los 86 diputados americanos, 25 eran eclesiásticos y 22 eran abogados o magistrados. Las provincias mexicanas estuvieron representadas por 14 eclesiásticos sobre un total de 28 diputados. Perú, en cambio, se inclinó más hacia los abogados y magistrados ( 8 sobre un total de 21 diputados). Los eclesiásticos eran simples párrocos aunque varios de ellos fueron obispos más tarde.

En Guanajuato o Zacatecas los "mineros" ganaron las elecciones; en Veracruz fueron los comerciantes; mientras que los diputados cubanos representaban la oligarquía azucarera esclavista. Algunos eran ricos, sobre todo los cubanos que vivían en Cádiz, los diputados de Lima, o el de Guayaquil, Vicente Rocafuerte; los de las regiones andinas, en cambio, tenían bienes modestos.

Pero aun los bienes pequeños podían perderse y por ello no hubo separatismo, por lo menos hasta que el retorno del absolutista Fernando VII los obliga a romper los vínculos coloniales $^{26}$. La representación se orientaba hacia un fidelismo acentuado. La voz de la América patriota se oyó poco en Cádiz. Para los diputados, la independencia política solo era una alternativa si la metrópoli no satisfacía sus reivindicaciones, no una meta en sí. La

24 Número extraordinario de la Gaceta de Buenos Aires (25/02/1811), "Discurso sobre la nulidad de las Cortes que se celebran en España", edición facsímil, Buenos Aires, 1910, vol. 2, pp. 92-94.

25 Fray Servando De Mier. "Manifiesto Apologético(Apéndice), San Juan de Ulúa 1820". En: J. M. Miguel I Verges y Hugo Díaz Thorme, Escritos inéditos de Fray Servando Teresa de Mier, Mexico 1944. pp. 153-154.

26 OSUNA N., María Isabel, «Perspectiva americana de las Cortes de Cádiz y la Constitución de 1812», Almirez, N. 3, 1994, pp. 77-87. MILLÁN-CHIVITE, José Luis, «Los diputados hispanoamericanos en las Cortes Constituyentes de la Isla de León y Cádiz (1810-1812)», Iberoamérica, N. ㅇ 4, 1986. CRUZ H., Emilio de la, «Hispanoamérica en las Cortes de Cádiz (relación de diputados)», Revista Mundo Hispánico, N. 311, 1974, pp. 42-43. 
representación regional que ellos asumían y que era prioritaria para sus electores, impidió un planteamiento "nacional" conjunto de los problemas.

Dos incidentes empujaron a los criollos a unirse y defenderse. Primero, la difusión en Cádiz de un fascículo escrito por el intendente José Gonzáles Montoya, donde critica gravemente al clero americano. El segundo fue la lectura pública de una representación del Consulado de México (27/05/1811), que acusa de demente al indio, de escoria a las castas y de disolutos a los criollos. Paradójicamente, concibe que la población la componen 5 millones de "autómatas" (indios y castas), un millón de "vasallos díscolos" (criollos) y "cien mil ciudadanos adictos al orden" (peninsulares).

En suma, los diputados americanos representaron bastante bien a la sociedad criolla blanca de la América colonial. La reforma que defendieron para la América española era una solución alternativa a la independencia absoluta; $\sin$ los «riesgos» de una revolución política ${ }^{27}$.

\section{Los cambios promovidos en las Cortes de Cádiz}

Diversos aspectos han sido auscultados de la realización de las Cortes: como roblema" ${ }^{28}$, desde un punto de vista nacional ${ }^{29}$, los presidentes $^{30}$, el vocabulario político ${ }^{31} \mathrm{o}$ los diputados ${ }^{32}$, entre muchos otros temas ${ }^{33}$.

Durante las Cortes extraordinarias (Constituyentes, septiembre de 1810-septiembre de 1813) se mantuvo cierta ambigüedad sobre la función de los diputados y sus obligaciones respecto de sus provincias. Ya no eran procuradores del Antiguo Régimen, pero tampoco "diputados" en el sentido definido por la Constitución: estaban en contacto permanente con sus provincias (Ayuntamientos, autoridades eclesiásticas, etc.) de las que recibían «instrucciones» que algunos consideraban como verdaderos mandatos ${ }^{34}$.

27 RIEU-MILLAN, Marie Laure, Los diputados americanos en las Cortes de Cádiz: igualdad o independencia. Madrid: C. S. I. C., XXIII, 1990. 438 p.

28 Como en CHUST C., Manuel, «Las Cortes de Cádiz y la problemática americana», en Congreso científico sobre la Historia de las Cortes de Castilla y León, Cortes de Castilla y León, 1990, volumen I, pp. 717-731. BLANCO V., Roberto L., «El problema americano en las primeras Cortes liberales_españolas», en VV. AA., Los orígenes del constitucionalismo liberal en España e Iberoamérica: Un estudio comparado, Sevilla, Junta de Andalucía/ Consejería de Cultura y Medio Ambiente, 1994, pp. 67-106.

29 REYES N., Salvador, «Las Cortes de Cádiz y las ideas políticas en México», en Los derechos del Pueblo Mexicano. Las Cortes de Cádiz, México, 1979. GUZMÁN, Martín Luis, Méjico en las Cortes de Cádiz, México, 1949. Ver BERRY, Charles R., «The election of the Mexican Deputies to the Spanish Cortes (1810-1822)», en BENSON, Nettie Lee (dir.), México and the Spanish Cortes (1810-1822). Eight essays, University of Texas Press, 1966, pp. 75-87. También de ANNINO, Antonio, «The Ballot, Land and Sovereignty: Cadiz and the Origins of Mexican Local Government, 1812-1820», en POSADA-CARBÓ, Eduardo, Elections before Democracy: The History of Elections in Europe and Latin America, London, MacMillan Press, 1996.

30 LABRA, Rafael, América y la Constitución Española de 1912 [sic. 1812]: las Cortes de Cádiz de 1810-1813. Madrid, 1914. 205 p. Los presidentes americanos de las Cortes de Cádiz: Estudio biográfico. Cádiz: Real Academia Hispano Americana de Ciencias y Artes, [1912]. 183 p. y otros.

31 GARCÍA G., María Teresa, Las Cortes de Cádiz y América. El primer vocabulario español y mejicano (18101814), Sevilla, Diputación de Sevilla, 1998.

32 VOLIO B., Marina, Costa Rica en las Cortes de Cádiz, San José, Juricentro, 1980. VILLACORTA, J. A., «Guatemala en las Cortes de Cádiz», Anales de la Sociedad de Geografía e Historia de Guatemala, XVII, 1941/1942, pp. 3-25. RODRÍGUEZ, Mario, El experimento de Cádiz en Centroamérica (1808-1826), México, Fondo de Cultura Económica, 1984. Edición inglesa 1978. GARCÍA L., Jorge Mario, Centroamérica en las Cortes de Cádiz,_México, F. C. E., 1971, y otros en la misma línea.

33 Véase BERRUEZO L., María Teresa, «El funcionariado americano en las Cortes gaditanas (1810-1813)», Cuadernos Hispanoamericanos N. ${ }^{\circ}$ 460, 1988, pp. 34-69. También ha trabajado la actuación de los militares, los ultraconservadores americanos, etc.

34 Ver Manuel FERNÁNDEZ M., Derecho parlamentario español, Madrid, 1885-1900, 3 tomos. «Instrucción que deberá observan para la elección de diputados en Cortes, 10 de enero de 1810», t. 2, pp. 574-590; «Instrucción para las elecciones de América y Asia, 14 de febrero de 1810», pp. 594-600. 
Las instrucciones de los Ayuntamientos a los propietarios de las Cortes extraordinarias indicaban lo que los electores exigían de sus diputados. Estaban divididas en tres partes: propios de la ciudad, derechos de sus habitantes y derechos del cabildo. Pedían la creación de cátedras de medicina; medidas para aumentar las rentas de la ciudad; alternancia entre peninsulares y naturales para los empleos; libertades económicas; baja de los censos de propiedades rurales; supresión de diferentes impuestos. También la "reducción" de indígenas y su catequización.

Las instrucciones se exponen desde una óptica local: se habla en nombre de la ciudad, de sus habitantes y de la provincia. El cabildo autoriza a su diputado, de forma muy general, a promover todo lo que parezca útil al bien de la Nación, y luego exponer las peticiones propias de la ciudad. Se expusieron ante las Cortes las reivindicaciones ya tradicionales de las ciudades americanas. El decreto del 14 de febrero inducía a este tipo de práctica, pero también los americanos siguieron considerando a sus diputados como apoderados hasta el final del período constitucional.

Las Cortes destituyen al aristocrático Consejo de Regencia para poner en su lugar a representantes del nuevo poder. Quince días más tarde, decretan la libertad de imprenta, decretan la abolición del régimen señorial, suprimen los señoríos jurisdiccionales, acaban con las prebendas eclesiásticas, prohíben la esclavitud y dictan severas medidas contra el maltrato a los indios y la expropiación de sus tierras.

Proponen transformar las vastas extensiones de terrenos yermos en poder de la aristocracia terrateniente feudal, del rey o comunales, en propiedad privada. Decretan que se venda la mitad de ellas para extinguir la deuda pública y la otra mitad, repartida gratuitamente por sorteo y a partes iguales, entre los soldados desmovilizados tras la guerra y entre los campesinos pobres. Revocan todas las leyes feudales relativas a los contratos agrícolas, los derechos abusivos de los mayorazgos, anulan el "voto de Santiago", establecen un impuesto de naturaleza profundamente progresista. Suprimen la Inquisición, decretan la abolición de los gremios, y con ello, la libertad económica, comercial, de trabajo y de fabricación.

Sin embargo, para cuando las Cortes de Cádiz concluyen su tarea legislativa, están aisladas del resto del país y sus medidas difícilmente encuentran un eco práctico. A pesar de la voluntad política de los diputados en mantener la unión del imperio hispánico, los debates parlamentarios pusieron de relieve los intereses divergentes de la metrópoli de las provincias de América, su desconocimiento mutuo. Lo que exigían los electores en general constituyen una serie de reformas de ámbito regional. Los diputados elegidos por las provincias eran portadores de reivindicaciones netamente locales. Las Cortes liberales, en cambio, pretendían elaborar una Constitución y unas leyes válidas para todo el Imperio, imponiendo un Estado unitario, con centro en Madrid, descentralizado por las Diputaciones provinciales.

Salvo excepciones, aquellos diputados no fueron ni agentes encubiertos de la independencia, ni "traidores" a sus patrias nacientes. Las ventajas del proyecto liberal justifican el que siguieran defendiendo los intereses de sus provincias dentro de la unidad hispánica. Como dice Rieu-Millán, la fidelidad a la madre-patria "ya no era un simple atavismo histórico, era una opción política".

En el Diario de sesiones, ${ }^{35}$ Rieu-Millán analiza el proyecto de reforma de las provincias ultramarinas defendido por sus diputados entre el 24 de septiembre de 1810 y el 10 de mayo de 1814. La tendencia natural de las provincias americanas fue regionalista; por eso sus diputados defendieron la creación de un Estado de autonomía ${ }^{36}$. Lo que pretendían era "volver atrás", e

35 Diario de las discusiones y actas de las Cortes. Cádiz, 1811-1813, 23 Vols.; Actas. de las Cortes ordinarias. Cádiz, 1813-1814, 4 Vols., 2 a edición. Diario de las Cortes generales y extraordinarias, Madrid, 1870, 8 Vols.; Actas de las Cortes ordinarias, Madrid, 1870,1 Vol.; Actas de las sesiones secretas de las Cortes. 8-10-1814, Madrid, 1874.

36 Según Rieu-Millan, la palabra "autonomía" no se empleó en Cádiz; los diputados americanos distinguían entre Estado unitario ("la unidad de gobierno" según Argüelles) y Estado federativo. Ellos intentaban conseguir una gran autonomía interna para las provincias, sin llegar a la formación de Estados federados. 
institucionalizar la situación anterior a las grandes reformas borbónicas, un Estado centralizado y cuya consecuencia práctica para América sería la de un mayor control metropolitano.

Con los dos elementos fundamentales resueltos por las Cortes, es decir, la igualdad del sistema representativo y el acuerdo de igualdad comercial, se sanciona el sistema representativo. Ademas de que revalida el decreto sobre fomento de la minería de azogue, dos resoluciones permiten la libertad de cultos, promueven la industria manufacturera y las artes, reconoce que americanos españoles e indios, e hijos de ambas clases, tienen igual opción que los españoles europeos para todos los empleos y destinos, así en la corte como en cualquier otro lugar de la monarquía, sean de la carrera eclesiástica, política o militar ${ }^{37}$.

Al igual que los diputados peruanos ${ }^{38}$, la representación de la Capitanía General de Venezuela fue leal a sus intereses. El diputado propietario José Domingo Rus, representante de Maracaibo, era el único titular por Venezuela, un ejemplo de funcionario ilustrado ${ }^{39}$. Tres fueron los representantes venezolanos; Rus, fiscal de Hacienda y abogado, dos suplentes: Esteban (de) Palacios, consejero de Hacienda y abogado y Fermín Clemente, abogado, ambos por Caracas ${ }^{40}$. Todos representantes de la élite local criolla.

Para Langue, Rus adoptó como la mayoría de los representantes americanos una postura relativamente moderada, una especie de "tercera vía": favorecer la participación de las provincias en el proceso político, otorgándoles alguna autonomía de decisión en el orden económico, político y cultural. En todo caso, no formó parte del sector ultra conservador ${ }^{41}$. Los tres fueron los representantes de una élite económica (dueños de haciendas) e intelectual (por su formación universitaria y su itinerario después de representar a Venezuela).

El diputado pronunció un discurso basado en sus instrucciones y presentaba los principales puntos de éstas en «proposiciones» formales (de alcance local) que pasaban a la Comisión correspondiente y seguían el curso parlamentario normal. Después de disolver las Cortes y abolir la Constitución, Fernando VII mandó que los representantes de América informasen al nuevo gobierno de las necesidades de sus provincias (junio 1814). Casi todos presentaron el contenido de sus instrucciones ante los nuevos poderes.

\section{La cuestión indígena en las Cortes}

En 1972 Armellada señalaba que: "la Causa Indígena Americana ocupó muchas y muy apasionantes sesiones de aquella ilustre asamblea hispanoamericana. Los españoles de la península y los españoles americanos, aun en medio de las angustias de la guerra de Independencia de España y de las guerras de secesion de la América española, dedicaron su atención fervorosa a muchas y graves cuestiones indigenas"42.

37 Para más detalles ver Demetrio RAMOS: «Las Cortes de Cádiz y América».

38 RAMOS, Demetrio, «El peruano Morales, un ejemplo de complejidad americana en las Cortes de Cádiz», Revista de Estudios Políticos N. ${ }^{\circ}$ 146, 1966, pp. 139-202. ALAYZA y Paz Soldán, Luis; Pons Muzzo, Gustavo La Constitución de Cádiz de 1812. El egregio limeño Morales y Duárez". Documenta: Revista de la Sociedad Peruana de Historia, $\mathrm{N}^{\circ}$ especial, Lima, 1948, 1(1) p. 465-466.

39 LANGUE, Frédérique, "La representación venezolana en las Cortes de Cádiz: José Domingo Rus". Boletín Americanista, Universidad de Barcelona (España), N 45, año XXXV, 1995, pp. 221-247.

40 Ver "Los tres diputados de Venezuela a las Cortes de Cádiz de 1810 a 1812", por Manuel Landaeta Rosales, El Nuevo Diario, 20 y 27 de septiembre, 17 de noviembre de 1915 (Hemeroteca de la Academia Nacional de la Historia, Caracas). Gallardo, Ricardo, "Las intervenciones de los diputados venezolanos en las sesiones de las Cortes de Cádiz (1810-1823)”, en El pensamiento constitucional de Latinoamérica 1810-1830, Caracas, Academia Nacional de la Historia, 1962, tomo II, p. 171, etc.

41 BERRUEZO, M. T., "Los ultraconservadores americanos en las Cortes de Cádiz (1810-1814)", Revista de Indias, XLVI: 177, 1986, pp. 169-198.

42 ARMELLADA, Cesáreo de, La causa indígena americana en las Cortes de Cádiz. Caracas, Universidad Católica Andrés Bello, 1979, p. 6. Armellada recuerda que fue la lectura de VILLAPADIERNA, Rvdo. Isidoro de, La cuestión religiosa en las cortes de Cádiz. (Tesis doctoral), la que estimuló su interés por el tema. 
Para Armellada el primero en levantar la voz a favor de los indios y que consigue de las Cortes el primer decreto indigenista es el Sr. Inca, en la sesión del 16 de diciembre de 1810.

Las cuestiones indígenas tocadas en las Cortes fueron en el orden siguiente: el 16 de dic. de 1810, Inca propone un decreto sobre protección de los indios, en tanto el 23 de enero de 1811 se ve el tema de la minoridad de los indios. El 20 de junio se discute sobre la Dotación de curas de indios, el 4 septiembre sobre la Ciudadanía de las castas. El 4 abril 1812 se debaten las proposiciones sobre aboliciones de mitas, repartimientos, servicio personal, reparto de tierras, pérdida de jornales a los indios y adjudicación de la cuarta parte de becas en los seminarios a los indios.

El 2 de enero de 1813 se discute sobre el Protector general de indios en Lima y finalmente, el 5 de septiembre 1813 se elabora el decreto sobre entrega de las misiones a los ordinarios.

Al comienzo la Regencia propuso el nombramiento de "defensores indígenas" en las Cortes, y el diputado gallego Quintana pidió que los indios fuesen representados por indios. Los diputados americanos no apoyaron mucho esta idea. Pero hubo gente como Fernández de Leiva, Morales Duárez, Andrés de Jáuregui, Mariano Mendiola, Antonio Joaquín Pérez y Florencio del Castillo que abogaron por los indios y mestizos y solicitaron igualdad de derechos para todas las castas. A pesar de todo, lograron en las Cortes eximir a los indios del tributo personal, abolieron los repartimientos y redujeron la mita o trabajo de aquellas en las minas.

Los representantes españoles demostraron un amplio desconocimiento de la realidad hispanoamericana ${ }^{43}$. Este desconocimiento los llevó a rechazar las peticiones de sus colegas americanos, haciendo ejercicio permanente del más radical y vergonzoso racismo cuando se debatieron soluciones a los problemas que afectaban directamente a los indios, negros, mestizos y castas.

El rechazo a las peticiones deriva de una contradicción ${ }^{44}$ o conflicto entre una sociedad civil y la comunidad católica, la República constituyente versus el derecho histórico, la Nación soberana versus la nación tradicional. En esa línea, Portillo ${ }^{45}$ considera que la modernidad política de la constitución de Cádiz sería limitada desde el punto y la hora en que consideró a la nación española como esencialmente católica. Por ello, en Cádiz se estaba produciendo una innovación, bajo la guisa de una necesaria búsqueda de puntos que uniera a lo que ya corría peligro inminente de romperse y desintegrarse ${ }^{46}$.

Los diputados americanos presentaron sus proposiciones, redactadas de forma coherente en once artículos y presentadas el 16 de diciembre de 1810. Es el primer cuerpo reivindicativo organizado de los representantes criollos, pero no aborda el "problema indígena". Los once artículos recogen las aspiraciones de la sociedad criolla, principalmente la igualdad para los empleos y libertades económicas.

Hay dos alusiones a los indígenas. El Art. 8 dice que los americanos, así españoles como indios, y los hijos de ambas clases, tienen igual opción que los españoles europeos para

43 MARTINEZ, Pedro Pascual, La unión con España, exigencia de los diputados americanos en las Cortes de Cádiz, Madrid, Consejería de Educación, 2001. Algunos diputados veían que ciertos colegas eran "cortísimos en talento e instrucción", como advierte Villanueva de su colega Vera, en VILLANUEVA, Joaquín Lorenzo, Mi viaje a las Cortes,_Madrid, Imprenta Nacional,1860. p. 259.

44 VILlaCAÑAS V., José Luis, La Nación Católica. "El problema del poder constitucional en las cortes de Cádiz”. En Relatos de Nación. La Construcción de identidades nacionales en el mundo hispánico. 2 tomos. CSIC, Instituto de Filosofía. O. E. A., España, 2005.

45 PORTILLO V., José María, Revolución de la nación: orígenes de la cultura constitucional en España (17801812), Centro de Estudios Políticos y Constitucionales, BOE, Madrid, 2000.

46 GARCÍA G., María Teresa, Las Cortes de Cádiz y América. El primer vocabulario español y mejicano (1810-1814), Sevilla, Diputación de Sevilla, 1998. 
toda clase de empleos y destinos, así en la Corte como en cualquier lugar de la Monarquía, sea de la carrera eclesiástica, política o militar. El artículo 1 pedía para América la misma representación en Cortes que la de España, representación calculada sobre la base de la población "española", indígena y mestiza, proposición consecuente del decreto del 15 de Octubre de 1810. En cuanto al artículo 8, se trata de una declaración de principios y buenos deseos.

Al parecer, que no cuajara la preocupación legal por el indígena en los once artículos no fue por olvido, sino porque los americanos no consiguieron ponerse de acuerdo. A lo largo del mes de diciembre de 1810, el diputado suplente del Perú, Inca Yupanqui, había presentado varias proposiciones relativas a la libertad e igualdad de los indígenas ${ }^{47}$. Todo indica que Inca no consiguió recoger la adhesión de sus colegas, ya que estas proposiciones no se incluyeron finalmente en los artículos.

Anteriormente, el día en que estos artículos fueron presentados ante las Cortes, Inca Yupanqui tomó la palabra "como inca, indio y americano", a favor de los indígenas y presentó una fórmula de decreto para ordenar que los Virreyes, Presidentes de Audiencias, Gobernadores etc. "se dediquen con particular esmero y atención" a proteger a los indios y prohibir que persona alguna constituida en autoridad eclesiástica, civil o militar, ni otra alguna de cualquier clase o condición que sea, aflija al indio en su persona, "ni le ocasione perjuicio el más leve en su propiedad....."48.

El decreto, aprobado el 5 de enero de 1811, es la primera disposición indigenista de las Cortes y recuerda las leyes protectoras existentes. El diputado Inca Yupanqui pronunció un discurso muy general sobre la opresión padecida por América, discurso muy aplaudido, tal vez debido a la personalidad del orador. Es difícil saber si Inca decidió pronunciar este discurso ante la ausencia de toda referencia al indio en los once artículos.

Por supuesto que los diputados americanos presentes en los primeros meses de las sesiones no eran insensibles a la situación de los indígenas. De hecho, el 2 de octubre de 1810 , un diputado tomó la palabra para exponer las vejaciones padecidas por los indios. En todo caso, se dudaba entre una política de integración civil, que aparece en los artículos 1 y 8 , y la política tradicional de protección legal.

Al respecto, el texto del Decreto de 5 de enero es significativo. Prohibe a las autoridades eclesiásticas, civiles y militares vejar a los indios en su persona y en sus propiedades. En cuanto a sus privilegios, ordena también que los protectores de los indios se esmeren en cumplir debidamente el sagrado cargo de defender su libertad personal, sus privilegios y demás exenciones ${ }^{49}$.

Los diputados eran conscientes de los peligros que podía acarrear para los indígenas la abolición de sus privilegios legales. El texto del decreto es una especie de compromiso, que mantiene temporalmente estos privilegios, y al mismo tiempo intenta asegurar a los indígenas el goce de dos de los principales "derechos del ciudadano"; el derecho a la propiedad y el derecho a disponer de sí mismo. Este decreto refleja la esencia de lo que fue la política indigenista en las Cortes.

47 Según VILLANUEVA, Joaquín Lorenzo, "Mi viaje a las Cortes de Cádiz”, Madrid, 1960. en Memorias del Tiempo de Fernando VII, editor Miguel Artola, Madrid, 1957.

48 Diario de Sesiones del Congreso de los Diputados: Cortes de Cádiz: 24 de septiembre de 1810 a 20 de septiembre de 1813 / Congreso de los Diputados. Madrid: Congreso de los Diputados, 2000, p. 57.

49 GIBERT, Rafael, «Colección de Decretos de las Cortes, 1810-1813», en Actas del IV Symposium de Historia de la Administración, Madrid, Instituto Nacional de Administración Pública, 1983, pp. 299-324. 


\section{La condición jurídica de los indigenas y la ciudadanía}

Recientes estudios han retomado las investigaciones sobre la cuestión indígena presente en las Cortes, destacando autores como Díaz ${ }^{50}$, Escobar $^{51}$, entre otros ${ }^{52}$. Frente a la vieja idea de que los indígenas no tuvieron mayor protagonismo en las elecciones y representaciones, Rodríguez $^{53}$ observa que en realidad, desde 1946, hubo una tendencia historiográfica en ver solo las ciudades, como espacios de lucha por la independencia, e indígenas ignorantes absolutos del proceso.

Tal idea fue revisada en los estudios de Guarisco, Rugeley, Escobar y Ducey, de Guardino sobre Oaxaca y Guerrero, la investigación de Avendaño y Dym sobre Guatemala, de Almer sobre Venezuela y del mismo Rodríguez acerca de Oaxaca, Guadalajara, Quito y Guayaquil, demostrando que la poblacion indígena, incluidos mulatos y mestizos, estaba enterada y entendía el significado del nuevo orden constitucional y, por lo tanto, tomaba en serio su nuevo papel de ciudadanos.

Así, el libro de Guarisco analiza el impacto de la constituciòn gaditana en la redefinición de la sociabilidad política a través de la creación de nuevos ayuntamientos, en las que los indios mantuvieron sus costumbres representativas y autonomistas. Así, fueron los indígenas quienes sentaron las bases de esa nueva sociabilidad polìtica híbrida, caracterizada por la ausencia de un sentido de pertenencia a la Nación y a la soberanía, y por la presencia de una profunda lealtad al Rey, sociabilidad que se consolidaría en los años siguientes ${ }^{54}$.

El debate sobre el estatuto jurídico de los indios comenzó en el marco de la discusión sobre la representación en las Cortes de las provincias americanas. En las disposiciones anteriores a 1810, los indígenas eran considerados como representables y elegibles, pero el sistema elaborado para América aseguraba la inferioridad numérica de su representación, y apartaba prácticamente a los indios del ejercicio electoral (elecciones por las capitales de provincias $)^{55}$. Los diputados criollos reivindicaban la igualdad representativa en el modo electoral (popular, en las que participarían los indígenas) y en la proporción de diputados con respecto a la población.

Fue entonces cuando algunos peninsulares cuestionaron la aptitud de los indígenas para ejercer los derechos de ciudadanos. El diputado sevillano Valiente se opuso a la concesión de la ciudadanía al indígena (23/01/11): "Es tal la pequeñez de su espíritu, su cortedad de ingenio, su propensión al ocio...que al cabo de tres siglos de oportunas y empañadas providencias para entrarlos en las ideas comunes y regulares, se muestran iguales a los del tiempo del descubrimiento de las Indias" $" 56$.

50 DÍAZ R., Carlos, «Las Cortes de Cádiz y el indio americano. Las_normas y su incidencia: el caso andino», Revista de Historia del Derecho Ricardo Levene, n. 27, 1990, pp. 79-97. Del mismo, "Cádiz entre indígenas: Lecturas de la Constitución y_su cultura en tierra de los mayas», Anuario de Historia del Derecho Español, tomo LXV, 1995, pp. 931-992.

51 ESCOBAR O., Antonio, "Del gobierno indígena al ayuntamiento constitucional en los huasteques hidalguense y veracruzana, 1780-1853". Mexican estudies/ estudios mexicanos, 12/1 (invierno, 1996), p. 1-26.

52 CASTILlO, Francisco; FIGALLO, Luisa J.; SERRERA, Ramón, Las Cortes de Cádiz y la imagen de América. La visión etnográfica y geográfica del Nuevo Mundo, Cádiz, Secretariado de Publicaciones de la Universidad de Cádiz, 1994.

53 RODRIGUEZ, Jaime, La ciudadania y la constitución de Cadiz, p. 39-56. En FRASQUET, Ivana (coordinadora). Bastillas, cetros y blasones. La independencia en Iberoamérica. Instituto de Cultura, Fundación MAPFRE. Madrid, 2006. 390 p.

54 GUARISCO C., Claudia, Los indios del valle de México y la construcción de una nueva sociabilidad política. 1770-1835. México, el Colegio Mexiquense AC, 2003.

55 Véase al respecto el trabajo de SERRANO, José Antonio. "Votos, contribuciones y milicias en Guanajuato, 1810-1847. Los vínculos militares, fiscales y electorales entre las elites políticas y los vecinos principales", México, El Colegio de México, Tesis de doctorado (1998), 2001.

56 TIERNO GAlVÁn, Enrique (ed.), Actas de las Cortes de Cádiz. Antología, Madrid, Taurus, 1964, colección Biblioteca Política. 
El indio es, según Valiente, incapacitado, naturalmente estúpido y legalmente menor, no puede ejercer el derecho al voto. Incluso añade un argumento: el voto de los indígenas sería manipulado a favor de los criollos. El Semanario Patriótico N. ${ }^{\circ} 46$, de 22 de febrero, acusa que los indios estarían representados por sus propios opresores: "sería nombrar al lobo procurador del cordero", en los que el lobo ya no es el conquistador español sino el opresor criollo ${ }^{57}$.

La opinión de Valiente se funda en un concepto tradicional y denigrante del indígena ${ }^{58}$. Aunque pocos peninsulares emitieron juicios tan peyorativos, los representantes ultramarinos temían al diputado Valiente, porque era uno de los pocos peninsulares que conocían América, y sus opiniones eran muy consideradas. Los criollos intentaron refutar los argumentos del diputado sevillano. Pero a la vez, no apoyaron al diputado García Quintana, ni al suplente de Buenos Aires, López Lipegüe, quienes afirmaban que los indios debían ser representados por indios.

Los representantes de América desarrollaron una defensa del derecho de ciudadanía indígenas con ciertos límites. Morales Duárez prefirió defenderlos recurriendo a los autores españoles. Para refutar al Obispo Arias y Quevedo, Morales se situó en la larga tradición del pensamiento indigenista. Citó a Bartolomé de las Casas, a miembros de la jerarquía eclesiástica, a historiadores que elogiaron a los primeros habitantes de América, como Garcilaso de la Vega.

El tema del indio oprimido tenía una resonancia particular en la sensibilidad peninsular ${ }^{59}$. Por ejemplo, el diputado García, tras haber insistido sobre las vejaciones y estafas que han padecido "esos pobrecitos indios" (11/01/1811) concluye: “¿No es verdad, generosos criollos y justos europeos, que sentís en este momento una emoción interior que arrebata toda vuestra sensibilidad?". Los criollos supieron tocar esta fibra sensible. De hecho, todas las leyes indigenistas que propusieron fueron aprobadas por amplia mayoría o por unanimidad de votos, al menos en primera instancia.

\section{Abolición del tributo indígena}

La primera medida para integrar a los indígenas en el cuerpo de la Nación ha sido la abolición del tributo, votada el 12 de marzo de 1811. Las Cortes aprobaron tal abolición, adoptada por el Virrey de México Francisco Javier Venegas, y la extendieron a toda América. La idea no era nueva, pero el tributo indígena proporcionaba gran parte de los recursos financieros, sobre todo de las provincias andinas, donde las autoridades coloniales se opusieron con decisión a esta medida.

En febrero de 1811, la Contaduría General de Tributos de Lima presentó un informe sobre las reformas indigenistas que ya estaban a la orden del día: la abolición del tributo y de todos los servicios personales, y la distribución de tierras en propiedades privadas. La argumentación de la Contaduría es ejemplar: el tributo se impuso tras la conquista como una especie de contrato, un signo de obediencia al Rey a cambio de construir iglesias para los indios y de administrarles justicia, es decir, que la mayor parte del tributo "se invierte en su propia conveniencia".

57 DE QUIRÓS, Bernaldo, «El pensamiento reaccionario en las Cortes de Cádiz», en FERNÁNDEZ ALBALADEJO, Pablo; ORTEGA LÓPEZ, Margarita, Antiguo Régimen y liberalismo. (3) Política y Cultura Homenaje a Miguel Artola, Madrid, Alianza Editorial, 1994, pp. 539-550.

58 DÍAZ R., Carlos, «Las Cortes de Cádiz y el indio americano. Las normas y su incidencia: el caso andino», Revista de Historia del Derecho Ricardo Levene, N. ${ }^{2}$ 27, 1990, pp. 79-97.

59 DEROZIER, A., «Argüelles y la cuestión de América ante las Cortes de Cádiz de 1810-1814», en GIL N., Alberto (ed.), Homenaje a Noël Salomon. Ilustración española e independencia de América, Barcelona, Universitat Autònoma de Barcelona, 1979. 
Además, el tributo da unos ingresos de 1.258.721 pesos anuales en el virreinato peruano, quedando 788.036 pesos para la Real Hacienda. La mita, prosigue la Contaduría, es necesaria para obligar a los indios a trabajar y luchar contra "su natural inclinación al ocio". En cuanto a distribuirles la propiedad de tierras pertenecientes a la Corona, la Contaduría piensa que la medida es inútil, porque los indios volverían a venderlas a bajo precio. Hay también razones de tipo político: "podrían descubrir otras ideas aun más contrarias a las disposiciones soberanas". En suma, era prudente seguir manteniendo a los indígenas en la situación de dependencia económica y legal.

Les sorprende el hecho de que el tributo haya sido abolido "casi sin discusión", sin que las Cortes hayan tomado medidas serias para compensar el déficit consecuente. Una medida sería que cada Virrey o Gobernador reuniera una Junta, compuesta por el Arzobispo, el Regente, el Intendente y los principales funcionarios de finanzas, para encontrar las medidas necesarias y compensar el tributo. No fue autorizado el repartimiento, como proponía el Virrey de México, para resolver parcialmente el problema. Las Cortes examinaron una memoria del Obispo de Michoacán, que también proponía la abolición del tributo y un aumento de ciertas tasas para resarcir la hacienda; y solo aprobaron, como medida compensatoria, la comercialización del aguardiente de mezcal, gravado por fuertes impuestos.

Esto explica que las autoridades coloniales hayan aplicado con mucha reticencia el decreto de abolición del tributo. El Virrey de Perú, Fernando de Abascal, aplicó formalmente el decreto, pero se quejó inmediatamente a las Cortes por la falta de medidas sustitutivas; el tributo era la fuente de ingresos más importante del virreinato, tanto para financiar la guerra contrainsurgente como para el funcionamiento ordinario de las administraciones.

Abascal intentó aumentar algunos impuestos, al tabaco por ejemplo, y sobre ciertas importaciones, lo que provocó fuertes críticas del periódico El Peruano; también recurrió a una suscripción voluntaria. Pero donde se manifestó todo el ingenio del Virrey fue en la creación de una «contribución provisional» y voluntaria. Este proyecto fue aprobado por la Junta de Tribunales, reunida en julio de 1812, conforme al decreto de abolición de marzo de 1811. Esta contribución, de un monto idéntico al tributo, sería pagada por los indios tributarios y percibida por los mismos agentes del fisco y en la misma época del año. Numerosos ayllus aceptaron "voluntariamente" someterse a esta contribución, por temor a nuevos impuestos.

En su circular a los gobiernos provinciales (20/11/12), el Virrey aconsejaba que por medio de los curas párrocos se hiciera entender a los indios "lo ventajosa y favorable que será esta contribución sobre cualquiera otra que deba señalárseles para que como ciudadanos e igualados a los españoles hayan de contribuir según la Constitución para las cargas del Estado". Se les haría saber que, como ciudadanos, quedaban libres de mitas y demás vejámenes; los que decidieron pagar la contribución quedarían eximidos de las demás contribuciones propias de los españoles.

En 1815, Abascal se queja de que "las Cortes abolieron (el tributo) sin conocimiento, dejándose llevar de los dictámenes de varios perversos diputados, amantes del desorden revolucionario". A fines de 1810, la abolición del tributo ya había sido aprobada para México $^{60}$. Los diputados americanos eran conscientes de las dificultades que acarrearía esta medida, incluso, como dice Feliu, para los propios indígenas, a los que, antes o después, se extenderían los demás impuestos ordinarios (alcabala, diezmos u otros). Esto causó divergencias en el grupo criollo.

60 GARZA, David T., «Criterio constitucional mexicano en las Cortes de Cádiz», en México y las Cortes españolas: ocho ensayos, Instituto de Investigaciones Legislativas, México, 1985, pp. 51-65. LOHMANN V., Guillermo, "Notas sobre la presencia de la Nueva España en las Cortes metropolitanas y de Cortes en la Nueva España en los siglos XVI y XVII”, Historia Mexicana, Vol. XXXIX (1), núm. 153, 1989, pp. 33-40. 
Por ejemplo, el 20 de junio de 1811, Inca Yupanqui defendió con entusiasmo la abolición del tributo "que va a derramar el consuelo y la prosperidad entre aquellos inocentes hermanos"; a la vez, propuso también la distribución de tierras en propiedad privada. Según Inca, tales medida igualarían a indios y "españoles", borrando "la línea divisoria y degradante" entre ellos.

\section{La libertad individual del indígena}

Las disposiciones de las Cortes para liberar a los indígenas de los servicios forzados y de los castigos corporales, son una consecuencia lógica de su nuevo estatuto y de los preceptos constitucionales, como ciudadanos de pleno derecho, con penas correspondientes a sus delitos. Estos asuntos no fueron objeto de polémica: todos los diputados estaban de acuerdo sobre los principios.

La abolición de la mita fue propuesta por Florencio del Castillo, el diputado de Costa Rica, el 4 de abril de 1812, al mismo tiempo que otras medidas favorables a los indígenas ${ }^{61}$. Pedía que se eximiera al indio de los servicios personales al cura y a otros funcionarios públicos, de los trabajadores municipales colectivos, para mantenimiento de edificios públicos o de caminos; también pedía que no se les empleara demasiado en el servicio de las cofradías y de las sacristías. La comisión aprobó todas estas medidas, votadas por las Cortes el 21 de octubre de 1813.

Se trataba de liberar a los indios de tareas que los apartaba del laboreo de la tierra. La cuestión de la mita suscita una ligera discusión, pues se entiende que la mita solo existe en las regiones andinas, donde unos cuantos pueblos mandan todavía mitayos a Potosí y Huancavelica ${ }^{62}$.

Pero los propietarios de minas, por medio del Tribunal de Minas de Lima y de sus representantes en España, reclamaron insistentemente el derecho a emplear más mitayos, debido a la escasez de mano de obra, una grave dificultad que afrontaba la minería en el Perú. Las reivindicaciones de los propietarios de minas llegaron hasta las Cortes. El suplente Blas Ostolaza propuso que cada partido mandase obligatoriamente un numero determinado de mitayos. Todos los habitantes estarían sometidos a esa leva forzosa, no solamente los indios; es decir, proponía una extensión social de la mita.

En marzo de 1812, las Cortes recibieron una representación del apoderado del Tribunal de Lima en España, Luis Gargollo, que pedía una extensión territorial de la mita. Esto fue acaso lo que impulsó al diputado Castillo a pedir su abolición formal al mes siguiente. La Regencia presentó un informe contrario a la proposición de Ostolaza, leído en la sesión del 21 de octubre de 1812. La Regencia recordaba las leyes existentes para procurar moderar la crueldad de la mita, "servicio insoportable y destructor". Afirmaba que "el imponer un gravamen de esta naturaleza a todo un pueblo es una de las mayores desgracias que pueden sobrevivir" y que la proposición del diputado equivalía a "someter todas las clases a la particular de los mineros".

La Regencia se permitió incluso reconvenir al diputado Ostolaza; citó la ley XII, libro VI, titulo 12 de la Recopilación, que recomendaba velar sobre la conservacion de los indios, más que sobre el rendimiento de las minas, y añadió: "Mandato bien digno de que lo tenga presente un diputado del pueblo", a que se observe con puntualidad y oponerse

61 Ver BERRUEZO L., María Teresa, «El funcionariado americano en las Cortes gaditanas (1810-1813)», Cuadernos Hispanoamericanos, N. ${ }^{\circ} 460,1988$, pp. 34-69.

62 John FISHER, Minas y mineros del Perú colonial, 1776-1824. Instituto de Estudios Peruanos, Lima, 1977. ALAYZA y Paz Soldán, Luis; Pons Muzzo, Gustavo, "La Constitución de Cádiz de 1812. El egregio limeño Morales y Duárez”. Documenta: revista de la Sociedad peruana de historia, № especial:, Lima, 1948, 1(1) p. 465-466. 
enérgicamente cuando se le afecte. Sin proponer la abolición de la mita, el ejecutivo aconsejaba a las Cortes mayor prudencia en la discusión de esa proposición y deseaba ver adoptada "una medida que tenga por objeto aliviar a los afligidos indios, sin menoscabar la industria y la agricultura".

El 24 de octubre de 1811, el representante de Piura, José Antonio Navarrete, leyó un discurso bastante corto para pedir la abolición de la "mita de faltriquera", cuestión que había pasado totalmente desapercibida en el debate anterior. Navarrete afirmó que las minas de Huancavelica empleaban a 3.285 mitayos en el siglo XVI, pero solo quedaban 447 a principios del siglo XVIII, porque numerosos partidos pagaban un impuesto (la mita de faltriquera) a los dueños de minas.

Navarrete indica que esta exacción pecuniaria, en general tolerada y a veces perseguida, fue siempre ilegal, impuesta por particulares, y además en monto excesivo. El diputado solicitó (y obtuvo) la abolición de esta mita y la promesa de que los pueblos que pagaban este tributo serían compensados en lo posible por distribuciones de tierras. El primer decreto de la abolición de la mita, aprobado el 21 de octubre, fue modificado y redactado por términos más concretos para abarcar todas las variedades de servicios a los que estaban sometidos los indígenas.

El 13 de agosto de 1813 se leyó en sesión una exposición de los indios de Lambayeque, quejándose de que los curas los sometieran a castigos corporales (látigo y cárcel) cuando no asistían a la catequesis para personas adultas, tratados "como niños de escuela". Ante la incredulidad de los peninsulares que afirmaban que ninguna ley autorizaba esas prácticas, varios americanos intervinieron para confirmar su existencia. Los castigos corporales fueron abolidos el 5 de septiembre de 1813 .

\section{El indígena y la propiedad de la tierra}

El indígena, como ciudadano, sería libre de elegir la ocupación económica más conveniente a sus necesidades, ante todo la agricultura. La cuestión de la propiedad indígena, abordada en varias ocasiones, era un caso particular en un problema general. En los debates, las Cortes distinguieron cuatro tipo de tierras susceptibles de ser distribuidas: los baldíos y realengos, los propios pertenecientes al pueblo, los ejidos, las tierras de las comunidades o desmembradas parcialmente en propiedad privadas.

Todos los diputados proclamaron el derecho indígena en acceder a la propiedad. La distribución de tierras propuesta por Florencio del Castillo (04/04/1812) tenía por objeto "la estimulación al trabajo": el indígena se integraría así a la vida económica nacional. En los andes, los indios que poseían una tierra, integrada en un ayllu, eran menos numerosos que los "forasteros" sin tierra; estos trabajaban en las haciendas de los criollos o cultivaban tierras arrendadas en los ayllus; los yanaconas vivían en situación de servidumbre al servicio de los grandes propietarios.

Para estas dos últimas categorías de indios, la distribución de tierras era la mejor solución. El diputado de Nuevo México, Pedro Pino, dejó un testimonio de la miseria que observó al atravesar Nueva España y llegar a Veracruz; quedó sorprendido por la gran cantidad de vagos y mendigos: "Mi corazón se conmovió demasiado al observar por todos partes el hambre, la desnudez, y todos los efectos del estado más triste en que puede vivir el hombre".

La causa de esta miseria sería la falta de tierra y su distribución en propiedad privada remediaría la pobreza y apagaría el fuego de la rebelión. El 12 de marzo de 1812, las Cortes discuten un decreto de la Regencia ratificando la abolición del tributo por el virrey de México, y autorizándole a distribuir las tierras a los indígenas. Se decidió por las de 
baldíos y realengos, y que las tierras de los pueblos de indios solamente se distribuirían a los habitantes desprovistas de ellas. El diputado español García Herreros propuso que las tierras distribuidas a las casas de indígenas fuesen inalienables, porque la experiencia muestra que los vuelven a vender. Argüelles adujo que se atacaba "directamente el derecho de propiedad"; el peligro era que estas tierras volvieran a vincularse: "el mayor inconveniente resultaría que estos bienes se amayorazgasen, quedando así excluidos de la circulación" 63 .

La ley debía favorecer la libre circulación de la propiedad rural; su propósito no era resolver un problema social, sino un problema económico, reduciendo mejores superficies de tierras a cultivo. Pero, dice Argüelles, "las tierras en manos de indios sin capital para reducirlas a cultivo son inútiles, que no pueden producir fruto alguno espontáneo". Como no se preveían repartos de instrumentos o animales de labranza, "es indispensable que a falta de otro árbitro recurran al de la enajenación de alguna parte de ella para invertir su producto en la compra de aperos y animales con que hacer fructificar la que se reserva". Así, las tierras de los pueblos de indios, protegidas por las leyes anteriores, podían ahora pasar legalmente a manos de los grandes propietarios ${ }^{64}$. Estas ideas de Argüelles fueron recogidas en los dos primeros artículos del decreto del 4 de enero de 1813.

La comisión presenta su dictamen el 21 de octubre de 1812. Aprueba el principio del reparto de tierras. En cuanto a que este repartimiento se haga de las tierras de comunidad, la comisión encuentra dificultades. Se ha mirado siempre como algo sagrado las tierras de comunidad de indios, porque en ellas trabajan sus labores llamadas de comunidad, y porque cada individuo tiene el uso de aquella porción que puede cultivar, así también de las maderas y otros frutos en la parte que necesita.

El dictamen fue aprobado. Las cortes no desmembrarán las comunidades, pero las comunidades eran toleradas más que protegidas, pues era legal distribuir hasta la mitad de las tierras que se juzgaban demasiado extendidas.

\section{La educación del indígena y el clero}

Los diputados criollos se preocuparon por la educación, especialmente la indígena. Su educación era una condición previa necesaria a la integración en la sociedad "española"; se trataba de enseñarles el castellano, los principios de la doctrina cristiana, a leer y escribir. La educación estaba tradicionalmente unida a la catequesis; aplicados a los indígenas, eran inseparables y contribuían al mismo proyecto político ${ }^{65}$.

Para algunos diputados, los indígenas son culturalmente inferiores. Su desconocimiento del castellano, su mala asimilación de la "doctrina", la pervivencia de usos ancestrales eran síntomas de su ignorancia; pero el indio era apto también para el saber, "no solo para la industria y comercio, sino también para las ciencias naturales y abstractas". Cárdenas dice "que solo deben llamarse incultos, que lastimosamente lo sean sin culpa suya", pero "dotados de la luz natural de la razón". Desmiente el tópico de la torpeza intelectual o la estupidez natural del indio.

El clero vivía en contacto con la masa indígena y las "civilizaba". En los pueblos de indios alejados o en las regiones con población dispersa, el cura era a menudo el único punto de

63 ARMELLADA, Cesáreo de. La causa indígena americana en las Cortes de Cádiz, 1959. 110 p.

64 Bolívar emitió un decreto, fechado en Trujillo el 8 de abril de 1814, inspirado en los mismos principios: se distribuirían a los indios en plena propiedad las tierras de la Corona española y de las comunidades, «para que puedan venderlos o enajenarlas de cualquier modo».

65 Véase al respecto a ESPIGADO T., Gloria, «La Educación Primaria en el Cádiz de las Cortes», Trocadero: Revista de Historia Moderna y Contemporánea, N. ${ }^{\circ}$ 6/7, 1994, pp. 181-202. 
contacto de los habitantes con el exterior. Estos doctrineros eran un elemento importante de control del mundo indígena. En los curatos demasiado grandes, en las inmensas extensiones andinas, los curas no pueden administrar los sacramentos ni enseñar la doctrina, "lo que induce otros graves males por mantenerse los naturales sin sociedad, sin civilización, sin reunión, sin conocimiento, de Dios ni del rey, y aun sin sentimientos de humanidad. Esta ignorancia ... para crecer en vicios, y a sus mandones para hostilizarlos, para estafarlos y para robarlos, sin recurso de que haya quien les proteja y defienda".

La cuestión de la retribución de los curas de indios del Perú, tras la abolición del tributo con el que eran remunerados, era delicada. En efecto, para los indios los curas son «árbitros de toda su creencia, así religiosa como civil y política... son...dueños absolutos del indio», dice Morales (20/06/11), por eso era importante pagarles correctamente. Las Cortes rechazaron una Memoria sobre este asunto, presentada por el Ministro de hacienda de Indias, así como varios informes de la comisión. En su último dictamen (febrero de 1812), esta insistía sobre el hecho de que los curas "son encargados y aun árbitros de la instrucción civil".

Los diputados de Ultramar se interesaban por la evangelización y la cristianización de los indios. Muchos de estos diputados eran eclesiásticos y todos consideraban que uno de los deberes primordiales de la Corona (y la justificación última de la presencia de los españoles en América) era la propagación de la fe entre los indígenas. La europeización de los indios debía tener lugar mediante una educación pacífica, pero no exenta de presión. Se pretendía que los indios asumieran comportamientos europeos (vestimenta, trabajo, vida en poblaciones aldeanas, etc.), en perjuicio de la cultura indígena.

\section{La Constitución de Cádiz}

La trascendencia de la Constitución de 1812 ha motivado numerosos estudios, acerca de la influencia francesa e inglesa en la formación de un constitucionalismo español ${ }^{66}$, las fuentes históricamente ligadas al pensamiento jurídico "hispánico" ${ }^{67}$, el "mito de Cádiz" (Bartolomé Clavero), su significado como Carta fundacional, en su primera etapa liberal ${ }^{68}$. Se ha estudiado también la potestad reglamentaria liberal inaugurada en las Cortes, los Derechos Humanos ${ }^{69}$, la valoración de las normas aprobadas y la estatura jurídica con especto a otras constituciones ${ }^{70}$, sobre la corta duración de sus efectos ${ }^{71}$ o defectos ${ }^{72}$, etc.

66 RAMOS S., Alberto, «La Constitución de 1812 en su contexto histórico», La Constitución de 1812, Sevilla, Fundación El Monte, 2000. ARTOLA G., Miguel (ed.), «Las declaraciones de derechos y los primeros textos fundamentales galos en los orígenes del constitucionalismo español», en MORAL S., Enrique (coordinación e introducción), España y la Revolución Francesa, Madrid, Pablo Iglesias, 1989, pp. 73-87. CRAWLEY, C. W., «French and English Influences in the Cortes of Cadiz. 1810-1814», Cambridge Historical Journal, volumen 6, N. . 2, 1939, pp. 176-208. Y otros.

67 SÁNCHEZ B., Ismael, las fuentes de la Constitución española de 1812», TOMÁS Y VALIENTE, Francisco, «Génesis de la Constitución de 1812, etc.

68 ALONSO C., Álvaro, La Constitución de 1812 y el inicio del constitucionalismo, Madrid, Fundación Santa María, 1985. Y otros como CAVERO L., Iñigo; ZAMORA, Tomás, MARTÍNEZ S., Manuel, etc.

69 VILLAMOR M., Elisenda de, «Derechos humanos y Libertades públicas en la Constitución de 1812», Anuario de la Facultad de Derecho de la Universidad de Extremadura, N. ${ }^{\circ} 14 / 15,1996 / 1997$, pp. 493-510. MARTÍNEZ QUINTEIRO, Esther.

70 FERNÁNDEZ G., Antonio, «Valor normativo y supremacía jurídica de la Constitución de 1812», en SÁNCHEZ F., Remedio; GARCÍA P., Mariano (coord.), La enseñanza de las Ideas Constitucionales en España e Iberoamérica, Valencia, Ene Edicions, 2001, pp. 185-199.

71 ¡Cien años de desdichas! (1812-1912): estudio crítico de la Constitución de Cádiz, Barcelona, Tipografía Católica, 1912. También «iLibraos de Ultramaria; El fruto prohibido de Cádiz», en IÑURRITEGUI, José María; PORTILlO V., José María (eds.), Constitución en España: orígenes y destinos, Madrid, Centro de Estudios Políticos y Constitucionales, 1998, pp. 109-137.

72 IWASAKI C., Fernando, «1812: ¿Constitución original o pecado constitucional?», Revista de Estudios Fronterizos, N. ${ }^{\circ}$ 2, 2004, pp. 163-173. ROURA G., Santiago A., «Supremacía y rigidez en la Constitución de 1812», Revista Jurídica de Navarra, N. ${ }^{\circ} 23,1997$, pp. 133-154. 
Asimismo, se hicieron investigaciones sobre la influencia de la Constitución liberal en Hispanoamérica $^{73}$, destacando en primer lugar los aportes renovados sobre México ${ }^{74}$. Por ejemplo, Chust y Serrano se refieren a la influencia del liberalismo y la trascendencia política de la constitución gaditana en $\mathrm{México}^{75}$. Otros dirigieron sus lentes a Centroamérica y Cuba, Venezuela ${ }^{76}$, analizando la presencia gaditana en el derecho constitucional liberal, o si las constituciones unitarias tuvieron graves diferencias con la opción federalista y descentralista, como en Argentina ${ }^{77}$.

De todos ellos se puede inferir que la influencia de la constitucion gaditana no fue general sino relativa, aplicada de manera parcial en territorio hispanoamericano ${ }^{78}$.

Cuando surgieron las resistencias de las provincias a la implantación del nuevo sistema legal, las Cortes prolongaron sus sesiones hasta septiembre de 1813, suspendiéndolas días antes de iniciarse la primera legislatura "ordinaria", reunida conforme a la Constitución. En mayo de 1814, el Rey abolió la Constitución y disolvió las Cortes, entonces reunidas en Madrid para la segunda legislatura "ordinaria". La Constitución fue acusada por Fernando VII (edicto del 4 de mayo de 1814) de ser una mera imitación de la Constitución francesa de 1791. Para Marx, fue un producto original de la vida intelectual española, que resucitaba antiguas instituciones nacionales e introducía reformas reclamadas por escritores y estadistas del siglo XVIII.

Desde que el 24 de septiembre de 1810 se elaborara su primer decreto (luego que los diputados que componen el congreso y representan a la Nación española, se declaran legítimamente constituidos en Cortes Generales y Extraordinarias, y que "reside en ellas la soberanía nacional"), por el cual los dominios españoles en ambos hemisferios forman una sola, misma monarquía y nación, una sola familia, y que por tanto, los naturales originarios de dichos dominios europeos o ultramarinos son iguales en derechos a los de la península, poco se había traslucido en la práctica.

Promulgada la Constitución en marzo de 1812, se estableció que la soberanía reside en la nación ${ }^{79}$ (ejerciéndola a través de sus representantes en las Cortes) y no en la monarquía, se procedió a la división de poderes, se impuso severas restricciones al poder real, se acaba con los privilegios estamentales, estableciendo la igualdad de los ciudadanos ante la ley, lo

73 MARTIRÉ, Eduardo, «Proyección del liberalismo gaditano en los Países de América», en Las Cortes de Castilla y León (1188-1988), Valladolid, Cortes de Castilla y León, 1990, volumen I, pp. 663-703. PETIT, Carlos y otros. MARCHENA F., Juan, «La Constitución de Cádiz y el ocaso del sistema colonial español en América», en La Constitución de 1812, Sevilla, Fundación El Monte, 2000.

74 ORTÍZ E., Juan, «Calleja, el gobierno de la Nueva España y la Constitución de 1812», Revista de Investigaciones Jurídicas, N. ${ }^{\circ}$ 20, 1996, pp. 405-447. ALBA, Manuel; PUGA Rafael de (eds.), La Constitución de 1812 en la Nueva España, México, Publicaciones del Archivo General de la Nación, 1912-1913. GONZÁLEZ, Luis; GIL CRESPO, Juan Antonio, etc.

75 Manuel Chust y José A. Serrano, Guerra, revolución y liberalismo en México, 1808-1835, p. 151-199.

76 VV. AA., Orígenes de la democracia constitucional en Centroamérica, San José, Costa Rica, Editorial Universitaria, 1976. NAVARRO G., Jesús, VILLABONA, María Pilar (estudio comparativo de las Constituciones de Venezuela y Cádiz), etc.

77 GARCÍA M., Roberto, «La Constitución española de 1812 como antecedente constitucional argentino», Revista de Estudios Políticos, N. ${ }^{\circ}$ 138, pp. 191-202. Del mismo «La Constitución de Cádiz y su influencia en el derecho constitucional argentino», Revista Argentina de Ciencia Política N. o 4, 1961. ALCÁNTARA S., Manuel, «Aproximación a los intentos de consolidación del sistema político argentino (1810-1826). Las Constituciones unitarias argentinas y la española de 1812», Materiales para el estudio de la Constitución de 1812, en CANO B., Juan (ed.), Sevilla, Parlamento de Andalucía/ Tecnos, 1989, pp. 23-38.

78 PALACIOS, Guillermo y Fabio Moraga. La independencia y el comienzo de los regímenes representativos. Historia contemporánea de América Latina. Volumen 1, 1810-1850. Editorial Síntesis. Madrid, 2003. p. 163.

79 En la Constitución de Cádiz (Art. $1^{\circ}$ y 5, 10), "la Nación española es la reunión de los españoles de ambos hemisferios" y no introduce ninguna disyuntiva en cuanto al derecho de ciudadanía o soberanía -América es parte de la nación que conforma la Monarquía española- y adquiere representación política. 
que además equivale al no reconocimiento de territorios con fueros distintos o especiales, se sancionan los derechos individuales a la educación, a la libertad de expresión, a la inviolabilidad del domicilio y a la propiedad.

En la nación española (restringida a los españoles de ambos hemisferios ${ }^{80}$ ); la ciudadanía se obtiene según el principio del ius sanguini, siendo requisito adicional la vecindad en los territorios de cualquier hemisferio; la naturalización mediante intervención especial de las Cortes, precedido del matrimonio con mujer española, y también el ejercicio de alguna actividad que contribuya al erario español. Los descendientes de españoles naturalizados podían ser considerados ciudadanos, cumplidos los requisitos de vecindad, mayoría de edad (21 años), y si con su trabajo contribuyese a los intereses de la nación. Los servicios especiales a la patria también son premiados con la nacionalidad, "aun cuando se tenga el estigma de ser originario del África", siempre que tales personas fuesen hijos de padres "ingenuos" (Art. 22).

Para el diputado Argüelles lo que hay es una reforma constitucional, por que a lo más que se atrevieron, fue a suplicar a los eclesiásticos que conservasen la pureza de la religión católica por "medios más suaves" que la de atormentar y quemar vivo a los que prevaricasen en la $\mathrm{fe}^{81}$. Fontana argumenta que no solo los diputados, sino la propia constitución dan testimonio de esa "ambigüedad y la moderación de esa política reformista" ${ }^{2}$. Muestra de esa ambigüedad es el decreto del 6 de agosto de 1811 que se limita a abolir los señoríos jurisdiccionales, mientras que los señoríos territoriales eran convertidos en "propiedad particular" ${ }^{83}$, permitiendo al señor salvar su tierra.

Por lo demás, la Constitución se ocupa de los indígenas solo de manera incidental. En su artículo 335, fracción X, dice: "Las diputaciones de las provincias de ultramar velarán sobre la economía, orden y progreso de las misiones para la conversión de los indios infieles, cuyos encargados les darán razón de sus operaciones en este ramo, para que se eviten los abusos... ${ }^{84}$ ".

En concreto, los indígenas no tienen ingerencia alguna como ciudadanos en la nación española. Uno de los últimos reductos que representaba una menguada autonomía política de los pueblos indígenas, y que existía en el momento de la promulgación de la Constitución, eran los cabildos indígenas, los cuales fueron anulados por la creación de los Ayuntamientos constitucionales de elección popular.

¿Qué tanto contribuyó la Constitución en la construcción de la ciudadanía en América? Por un lado, Rodríguez, explica cuáles eran las condiciones para ser ciudadanos y qué sentidos adopta la constitución al respecto ${ }^{85}$. Por otro, Serrano ha demostrado cómo la guerra y la legislación gaditana han repercutido en la región de Guanajuato, transformando la jerarquía territorial de esa región, en la medida en que las ciudades de mayor peso económico y que representaban políticamente a los habitantes de su jurisdicción y se

80 Art. $1^{\circ}$ de la Constitución de Cádiz. Para un análisis sobre el tema ver FERRER M. Manuel y Maria Bono López, Pueblos indígenas y Estado nacional en México en el siglo XIX, p. 47-48. En la misma obra ver "Comunidades indígenas versus ayuntamientos Constitucionales. pp. 378-386.

81 ARGUELLES, Agustín, La reforma constitucional de Cádiz (Estudio, notas y comentarios de Jesús Longares), Madrid, Iter S.A., 1970, p. 39.

82 FONTANA, Josep, La crisis del Antiguo Régimen, 1808-1833. Guías de historia contemporánea. 2 edición ampliada y revisada. Editorial Crítica, Barcelona, 1988, p. 16.

83 COLECCIÓN de los Decretos y Órdenes que han expedido las Cortes Generales y Extraordinarias desde su instalación en 24 de septiembre de 1810 hasta igual fecha de 1811. Madrid, Imprenta Nacional, 1820. p. 193-196.

84 FERNÁNDEZ G., Antonio (edición e introducción), La Constitución de Cádiz.(1812), y discurso preliminar a la Constitución, Madrid, Castalia, 2002, pp. 1-77.

85 RODRÍGUEZ O., Jaime E. "La ciudadanía y la constitución de Cádiz". Lecciones sobre federalismo $\mathrm{N}^{\circ} 5$, Universidad Autónoma de Zacatecas, México, 34 p. 
ocupaban de su gobierno, perdieron su importancia, permitiendo que las poblaciones sujetadas alcanzaran autonomía. Efectivamente, la guerra afectó mucho a Guanajuato, aumentando la influencia del liberalismo gaditano, lo cual coadyuvó a los cambios pero no los ocasionó. Estos cambios se dieron en los ayuntamientos, las diputaciones provinciales, las milicias cívicas y las elecciones ${ }^{86}$.

Para Annino, en la Constitución no fue modificada la definición de vecino; solo fue extendida a nuevos sujetos (los indios), pero conservó toda la indeterminación formal de la tradición. La carta gaditana transformó la comunidad local en una fuente de los nuevos derechos políticos. Annino valora la extensión de esta vecindad a la población indígena, extraordinaria para la época, pero sin deudas con el jacobinismo y con su vocación universalista de igualdad (los "negros y castas fueron excluidos de los nuevos derechos y la esclavitud se conservó").

La extensión de la ciudadanía liberal a los indios tuvo sus raíces en la época borbónica, cuando el jansenismo ilustrado español modificó el esquema teológico de Salamanca (siglo XVI). El indio de fines del siglo XVIII era considerado miserable materialmente, ya no espiritualmente, y su pobreza era considerada una limitación al desarrollo social. Si el indio en Cádiz accede a la igualdad liberal, es porque jansenistas y fisiócratas treinta años antes le habían reconocido el estatus de Homo economicus. Y si el indio es un vecino ciudadano, "entonces la comunidad indígena se vuelve una fuente de derechos constitucionales, como la blanca" $"$.

Vemos pues que las nuevas interpretaciones surgidas en los últimos años, han enfocado aspectos antes arrinconados, de la participación indígena durante el proceso de la independencia, especialmente aquellos relacionados a la realización de las Cortes de Cádiz y la Constitución, y que indudablemente nos permite comprender mejor la creciente importancia e influencia de los mismos en la historia política social de los países andinos.

86 SERRANO, José Antonio. "Votos, contribuciones y milicias en Guanajuato, 1810-1847. Los vínculos militares, fiscales y electorales entre las elites políticas y los vecinos principales", México, El Colegio de México, Tesis de doctorado, 1998, publicada como Jerarquía territorial y transición política, Guanajuato, 1790-1836. Zamora, el Colegio de Michoacán-Instituto Mora, 2001.

87 ANNINO, Antonio. Ciudadanía versus gobernabilidad republicana en México. Los orígenes de un dilema $\mathrm{p}$. 63-93. En SABATO, Hilda (coordinadora). Ciudadanía política y formación de las naciones. Perspectivas históricas de América Latina. Fideicomiso Historia de las Américas, F.C.E., México, 1999. Ver en este mismo libro El soberanos y su reino, Reflexiones sobre la génesis del ciudadano en América latina, de FrancoisXavier guerra. 